\title{
PERILAKU ORANG TUA DALAM PENCEGAHAN COVID-19 PADA ANAK USIA SEKOLAH DI KOMPLEK MUSTIKA GRIYA PERMAI DESA SUNGAI SIPAI KABUPATEN BANJAR TAHUN 2020
}

\author{
Iis Pusparina*, Riska Audia \\ Program Studi Diploma Tiga Keperawatan Stikes Intan Martapura, Indonesia \\ Email : pusparizani@gmail.com
}

\begin{abstract}
ABSTRAK
Coronavirus Disease 2019 merupakan penyakit menular yang disebabkan oleh Sars-CoV-2. Coronavirus menyebabkan penyakit mulai dari gejala ringan sampai berat. Saat ini peran orang tua masih kurang dalam pencegahan Covid-19 pada anak. Bahaya Covid-19 pada anak akan berdampak buruk pada kematian karena anak rentan terhadap penyakit. Tujuan penelitian untuk mengetahui perilaku orang tua dalam pencegahan Covid-19 pada anak usia sekolah. Metode penelitian ini adalah deskriptif, jumlah sampel 75 orang tua dengan tehnik purposive sampling. Pengumpulan data menggunakan kuesioner. Hasil penelitian menunjukkan perilaku orang tua dalam pencegahan Covid-19 mayoritas berperilaku baik. Selain itu, pengetahuan orang tua tentang Covid-19 mayoritas baik sebanyak 62 orang tua $(83 \%)$. Sikap orang tua mayoritas baik yaitu sebanyak 59 orang tua $(78,7 \%)$, sedangkan tindakan orang tua mayoritas baik sebanyak 67 orang tua $(89,3 \%)$. Diharapkan orang tua yang perilaku baik agar dapat mempertahankan dan meningkatkan perilaku yang lebih baik lagi dan orang tua yang perilakunya masih kurang diharapkan agar dapat menjadi lebih baik lagi dan ditingkatkan lagi.
\end{abstract}

Kata Kunci : perilaku, orang tua, pencegahan, covid-19, anak usia sekolah

\section{ABSTRACT}

Coronavirus disease 2019 is an infectious disease caused by Sars-CoV-2. The coronavirus causes illnesses ranging from mild to severe symptoms. Currently, the role of parents is still lacking in the prevention of Covid-19 in children. The danger of Covid-19 in children will have a negative impact on death as children are vulnerable to diseases. The aim of the study was to determine the behavior of parents in preventing Covid-19 in school-aged children. This research method is descriptive, the number of samples is 75 parents with a reasoned sampling technique. Data collection using a questionnaire. The results showed that the majority of parental behaviors in the prevention of Covid-19 were well behaved. In addition, the majority of parents' knowledge of Covid-19 was good, up to 62 parents (83\%). The attitude of the majority of parents is good, up to 59 parents (78.7\%), while the actions of the majority of parents are good up to 67 parents (89.3\%). Parents with good behavior are expected to be able to maintain and improve better behavior and parents whose behavior is even less expected to be even better and improved.

\section{Keywords: behavior, parents, prevention, covid-19, school age children}

Cite this as : Pusparina, I, Audia, R. (2021). Perilaku Orang Tua dalam Pencegahan Covid-19 pada Anak Usia Sekolah di Komplek Mustika Griya Permai Desa Sungai Sipai Kabupaten Banjar Tahun 2020. Jurnal Ilmu Kesehatan Insan Sehat, 9(1), 38-41.

\section{PENDAHULUAN}

Penyakit Coronavirus Disease 2019 (COVID19) meupakan penyakit menular yang disebabkan oleh Sars-CoV-2 yang menyebabkan penyakit mulai dari gejala ringan sampai berat. COVID-19 belum pernah http://jurnalstikesintanmartapura.com/index.php/jikis diidentifikasi sebelumnya pada manusia. (WHO, 2020).

Perilaku orang tua berperan penting pada masa pertumbuhan dan perkembangan anak usia sekolah yang memiliki karakteristik seperti suka bergaul dengan 
Iis Pusparina, Riska Audia, Perilaku Orang Tua dalam Pencegahan Covid-19

teman sepermainan di lingkungan sekitar rumah, lebih banyak aktivitas fisik sehingga beresiko terpapar sumber penyakit dan perilaku hidup yang tidak sehat (Hardinsyah dan Supariasa, 2016). Apalagi di masa pandemi virus corona ini, orang tualah yang banyak menghabiskan waktu bersama anak selama 24 jam. Orang tua wajib mengingatkan dan mengajari beberapa hal pada anak ketika keluar rumah atau bermain di luar rumah sesuai arahan protokol kesehatan Covid-19.

Di Benua Asia, Indonesia berada di peringkat ke 9, sedangkan di dunia Indonesia berada diperingkat ke 25 sebagai negara dengan jumlah kasus terbanyak positif Covid-19. Total kasus virus corona di Indonesia menjadi 62.142 orang. Untuk Provinsi Kalimantan Selatan menduduki peringkat ke 4 dari provinsi lainnya. Update data terbaru Sabtu, 04 juli 2020, jumlah pasien positif di Kalimantan selatan berjumlah 3.447 (Dinkes.Prof Kalsel 2020). Dan Kabupaten Banjar sendiri sudah menempati perigkat ke 3 dengan jumlah jumlah 359 pasien positif menurut data Dinas Kesehatan pada tanggal 04 Juli 2020. Sementara di Desa Sungai Sipai, ada 4 orang yang terkonfirmasi positif Covid-19 (Dinkes Banjar, 2020).

Orang tua sebagai individu terdekat anak harus terus mendisiplinkan anak agar selalu menerapkan kebiasaan baik sehingga tetap sehat dan terhindar dari virus COVID-19 ini, yaitu memberikan contoh saat keluar rumah atau saat bermain dan selesai bermain anak harus mencuci tangan dengan sabun, menggunakan masker, membatasi jarak, dan tidak bersentuhan langsung dengan teman sebayanya atau orang lain. Pentingnya prilaku orang tua untuk mengajarkan kepada anak agar selalu menjaga kebersihan dan kesehatan sejak anak sekolah merupakan salah satu cara efektif untuk menghindari terjadinya atau terpapar nya virus corona (Kemenkes, 2020).

\section{METODE}

Metode yang digunakan dalam penelitian ini adalah deskriptif. Populasi pada penelitian ini adalah orang tua yang mempunyai anak sejumlah 295 responden. Tekhnik penarikan sampel menggunakan purposive sampling. Sampel penelitian sebanyak 75 responden.

Data awal dikumpulkan dengan kuesioner, setiap responden diminta untuk mengisi kuesioner dengan link yang sudah peneliti kirim. Setelah semua responden mengisi kuesioner akan dilakukan pengolahan data.

\section{HASIL}

Tabel 1: Distribusi Karakteristik Responden Berdasarkan Usia, Jenis Kelamin, Pendidikan dan Pekerjaan Komplek Mustika Griya Permai Desa Sungai Sipai Kabupaten Banjar tahun 2020

\begin{tabular}{|c|c|c|c|}
\hline No & Variabel & $\mathbf{N}$ & $\%$ \\
\hline \multirow[t]{5}{*}{1.} & Usia & & \\
\hline & $20-35$ & 27 & $36 \%$ \\
\hline & $26-30$ & 10 & $13,3 \%$ \\
\hline & $31-35$ & 15 & $20 \%$ \\
\hline & $36-40$ & 23 & $30,7 \%$ \\
\hline \multirow[t]{3}{*}{2.} & $\begin{array}{l}\text { Jenis } \\
\text { Kelamin }\end{array}$ & & \\
\hline & Pria & 29 & $38,7 \%$ \\
\hline & Wanita & 46 & $61,3 \%$ \\
\hline \multirow[t]{7}{*}{3.} & Pendidikan & & \\
\hline & $\begin{array}{l}\text { Tidak } \\
\text { sekolah }\end{array}$ & 0 & $0 \%$ \\
\hline & SD & 2 & $2,7 \%$ \\
\hline & SMP & 6 & $8 \%$ \\
\hline & SMA & 38 & $50,7 \%$ \\
\hline & D3 & 10 & $13,3 \%$ \\
\hline & PT/Sarjana & 19 & $25,3 \%$ \\
\hline \multirow[t]{7}{*}{4.} & Pekerjaan & & \\
\hline & PNS & 19 & $25,3 \%$ \\
\hline & Swasta & 19 & $25,3 \%$ \\
\hline & Petani & 4 & $5,3 \%$ \\
\hline & Dagang & 6 & $8 \%$ \\
\hline & Buruh & 0 & $0 \%$ \\
\hline & $\begin{array}{l}\text { Tidak } \\
\text { bekerja }\end{array}$ & 27 & $36 \%$ \\
\hline Total & & 75 & $100 \%$ \\
\hline
\end{tabular}

Berdasarkan tabel 1 diketahui mayoritas responden berusia 20-25 sebanyak 36\%, berdasarkan jenis kelamin wanita $61,3 \%$, pendidikan terakhir SMA $50,7 \%$ dan tingkat pekerjaan mayoritas tidak bekerja yaitu sebanyak $36 \%$.

Tabel 2:Distribusi perilaku orang tua dalam pencegahan covid-19 pada anak usia sekolah di Komplek Mustika Griya Permai, Desa Sungai Sipai Kabupaten Banjar Tahun 2020

\begin{tabular}{llll} 
No & $\begin{array}{l}\text { Kategori } \\
\text { Perilaku }\end{array}$ & N & \% \\
\hline 1 & Baik & 63 & $84 \%$ \\
\hline 2 & Cukup & 12 & $16 \%$ \\
\hline 3 & Kurang & 0 & $0 \%$ \\
\hline Total & & 75 & $100 \%$ \\
\hline
\end{tabular}

Pada tabel 2 menunjukkan kategori perilaku orang tua dalam pencegahan covid-19 anak usia sekolah didapatkan mayoritas responden memiliki perilaku baik yaitu sebanyak 63 responden (84\%). 
Tabel 3: Tabulasi silang antara usia dengan perilaku

\begin{tabular}{|c|c|c|c|c|c|c|c|c|c|}
\hline \multicolumn{10}{|c|}{ Perilaku } \\
\hline \multirow{6}{*}{ Usia } & \multirow{2}{*}{ Kategori } & \multicolumn{2}{|c|}{ Baik } & \multicolumn{2}{|c|}{ Cukup } & \multicolumn{2}{|c|}{ Kurang } & \multicolumn{2}{|c|}{ Total } \\
\hline & & $\overline{\mathbf{N}}$ & $\%$ & $\mathbf{N}$ & $\%$ & $\mathbf{N}$ & $\%$ & $\mathbf{N}$ & $\%$ \\
\hline & $20-25$ & 23 & 30,7 & 4 & 5,3 & 0 & 0 & 27 & 36 \\
\hline & $26-30$ & 9 & 12 & 1 & 1,3 & 0 & 0 & 10 & 13,3 \\
\hline & $31-35$ & 11 & 14,7 & 4 & 5,3 & 0 & 0 & 15 & 20 \\
\hline & $36-40$ & 20 & 26,7 & 3 & 4 & 0 & 0 & 23 & 30,7 \\
\hline Total & & 63 & 84 & 12 & 16 & 0 & 0 & 75 & 100 \\
\hline
\end{tabular}

Berdasarkan tabel 3 menunjukkan antara perilaku dengan usia diperoleh hasil mayoritas

responden yang berusia 20-25 tahun memiliki tingkat perilaku yang baik sebanyak 23 responden $(30,7 \%)$.

Tabel 4: Tabulasi silang antara jenis kelamin dengan perilaku

\begin{tabular}{|c|c|c|c|c|c|c|c|c|c|}
\hline \multicolumn{10}{|l|}{ Perilaku } \\
\hline \multirow{4}{*}{$\begin{array}{l}\text { Jenis } \\
\text { kelamin }\end{array}$} & \multirow{2}{*}{ Kategori } & \multicolumn{2}{|c|}{ Baik } & \multicolumn{2}{|c|}{ Cukup } & \multicolumn{2}{|c|}{ Kurang } & \multicolumn{2}{|c|}{ Total } \\
\hline & & $\mathbf{N}$ & $\%$ & $\mathbf{N}$ & $\%$ & $\mathbf{N}$ & $\%$ & $\mathbf{N}$ & $\%$ \\
\hline & Pria & 24 & 32 & 5 & 6,7 & 0 & 0 & 29 & 38,7 \\
\hline & Wanita & 39 & 52 & 7 & 9,3 & 0 & 0 & 46 & 61,3 \\
\hline Total & & 63 & 84 & 12 & 16 & 0 & 0 & 75 & 100 \\
\hline
\end{tabular}

Berdasarkan tabel 4 menunjukkan antara perilaku dengan usia diperoleh hasil mayoritas

responden wanita memiliki tingkat perilaku yang baik sebanyak 39 responden $(52 \%)$.

Tabel 5: Tabulasi silang antara pendidikan dengan perilaku

\begin{tabular}{|c|c|c|c|c|c|c|c|c|c|}
\hline \multicolumn{10}{|l|}{ Perilaku } \\
\hline & \multirow{2}{*}{ Kategori } & \multicolumn{2}{|c|}{ Baik } & \multicolumn{2}{|c|}{ Cukup } & \multicolumn{2}{|c|}{ Kurang } & \multicolumn{2}{|c|}{ Total } \\
\hline & & $\overline{\mathbf{N}}$ & $\%$ & $\mathbf{N}$ & $\%$ & $\mathbf{N}$ & $\%$ & $\mathbf{N}$ & $\%$ \\
\hline & SD & 1 & 1,3 & 1 & 1,3 & 0 & 0 & 2 & 2,7 \\
\hline \multirow[t]{4}{*}{ Pendidikan } & SMP & 4 & 5,3 & 2 & 2,7 & 0 & 0 & 6 & 8 \\
\hline & SMA & 34 & 45,3 & 4 & 5,3 & 0 & 0 & 38 & 50,7 \\
\hline & D3 & 8 & 12 & 2 & 2,7 & 0 & 0 & 10 & 13,3 \\
\hline & PT/Sarjana & 16 & 21,3 & 3 & 4 & 0 & 0 & 19 & 25,3 \\
\hline Total & & 63 & 84 & 12 & 16 & 0 & 0 & 75 & 100 \\
\hline
\end{tabular}

Berdasarkan tabel 5 menunjukkan antara perilaku dengan pendidikan diperoleh hasil mayoritas perilaku yang baik yaitu sebanyak 34 responden responden yang berpendidikan SMA memiliki tingkat

Tabel 6: Tabulasi silang antara pekerjaan dengan perilaku

\begin{tabular}{|c|c|c|c|c|c|c|c|}
\hline \multicolumn{8}{|c|}{ Tingkat Perilaku } \\
\hline \multirow{8}{*}{ Pekerjaan } & \multirow{2}{*}{ Kategori } & \multicolumn{2}{|c|}{ Baik } & \multicolumn{2}{|c|}{ Cukup } & \multicolumn{2}{|c|}{ Total } \\
\hline & & $\mathbf{N}$ & $\%$ & $\mathbf{N}$ & $\%$ & $\mathbf{N}$ & $\%$ \\
\hline & PNS & 17 & 22,7 & 2 & 2,7 & 19 & 25,3 \\
\hline & Swasta & 16 & 21,3 & 3 & 4 & 19 & 25,3 \\
\hline & Petani & 3 & 4 & 1 & 1,3 & 4 & 5,3 \\
\hline & Dagang & 4 & 5,3 & 2 & 2,7 & 6 & 8 \\
\hline & Buruh & 0 & 0 & 0 & 0 & 0 & 0 \\
\hline & Tidak bekerja & 23 & 30,7 & 4 & 5,3 & 27 & 36 \\
\hline Total & & 63 & 84 & 12 & 16 & 75 & 100 \\
\hline
\end{tabular}



Berdasarkan tabel 6 menunjukkan antara perilaku dengan pekerjaan diperoleh hasil mayoritas responden yang tidak bekerja memiliki tingkat perilaku yang baik yaitu sebanyak 23 responden $(30,7 \%)$.

\section{PEMBAHASAN}

Berdasarkan tabel 2 mayoritas orang tua yang berusia 20-25 tahun memiliki tingkat perilaku yang baik. Perilaku dibentuk dari suatu proses dalam interaksi manusia dengan lingkungan (Notoatmodjo, 2010). Faktor lingkungan tersebut salah satunya meliputi usia. Jadi usia sangat berpengaruh terhadap perilaku karena pada usia dewasa awal, saat itulah perilaku terbentuk lebih spesifik. Dari hal tersebut pertambahan usia mempengaruhi perilaku seseorang, baik dalam berperilaku baik ataupun buruk.

Sejalan dengan hal terebut pada tabel 5 mayoritas orang tua yang berpendidikan SMA memiliki tingkat perilaku yang baik. Pendidikan mempengaruhi perilaku manusia, apabila penerimaan perilaku didasari pengetahuan, kesadaran, sikap positif maka perilaku akan bersifat langgeng (Notoatmodjo, 2014). Karena itu pendidikan sangat berpengaruh terhadap terbentuknya suatu perilaku, jika pendidikannya tinggi kemungkinan perilakunya juga akan semakin baik.

Sedangkan pada tabel 6 mayoritas orang tua yang tidak bekerja memiliki tingkat perilaku yang baik. Perilaku seseorang termasuk terjadinya perilaku kesehatan, diawali dengan pengalaman-pengalaman seseorang serta adanya faktor eksternal (Notoatmodjo, 2010). Jadi, tidak menuntut kemungkinan orang yang tidak bekerja mutlak berperilaku buruk, tergantung pengalaman masing-masing orang.

\section{KESIMPULAN}

Perilaku orang tua dalam pencegahan Covid-19 pada anak usia sekolah di Komplek Mustika Griya Permai Desa Sungai Sipai Kabupaten Banjar mayoritas tergolong perilaku baik sebanyak 63 responden (84\%).

\section{SARAN}

Diharapkan orang tua yang perilaku baik agar dapat mempertahankan dan meningkatkan perilaku yang lebih baik lagi dan orang tua yang perilakunya masih kurang diharapkan agar dapat menjadi lebih baik lagi dan ditingkatkan lagi.

\section{DAFTAR PUSTAKA}

Dinkes, Prof Kalsel, 2020. Data Covid-19 Provinsi Kalimantan Selatan 2020.

Kementerian Kesehatan RI, 2020. Pedoman Pencegahan dan Pengendalian Coronavirus Disease (COVID-19).

Kesehatan Republik Indonesia Nomor HK.01.07/MENKES/238/2020. Informasi Covid-19 di Indonesia.

Notoatmodjo, S. 2010. Metode Penelitian Kesehatan. Jakarta : Rineka Cipta 2014. Ilmu Perilaku Kesehatan. Jakarta : Rineka Cipta.

Shereen, Muhammad Adnan et.al. 2020. "Covid-19 Infection: Origin, Transmission, and Charasteriristics of Human Corona Viruses". Journal of Advanced Research (24) 91-98.

World Health Organization (WHO, 2020). Tentang Upaya Pencegahan Penyebaran Coronavirus Disease (COVID-19) Kepada Seluruh Masyarakat Indonesia (2020).Novel Coronavirus (2019-nCoV) 